American Journal of Biotechnology and Biochemistry 3 (2): 42-46, 2007

ISSN 1553-3468

(C) 2007 Science Publications

\title{
Potential Strain to Produce Bioprotein from Cheaper Carbon Source: Hope for Millions
}

\author{
Parveen Jamal, Md. Zahangir Alam and Nurul Umi \\ Bioenvironmental Engineering Research Unit (BERU), Department of Biotechnology Engineering \\ Faculty of Engineering, International Islamic University Malaysia (IIUM) \\ P.O. Box 10, 50728 Kuala Lumpur, Malaysia
}

\begin{abstract}
Bioprotein production is one of the most promising breakthroughs of biotechnological innovations. Due to its increasing demand, the efficient strains, substrate and method must be used for high yield product. In this study, screening of five different cerivisiea, Mucor hiemalis and Thricoderma harzianum, was done for bioprotein production by liquid state bioconversion of wheat flour as a cheaper carbon source. Bioconversion was done with fixed wheat flour concentration of $2 \%$ $(\mathrm{w} / \mathrm{v})$ at a temperature $27^{\circ} \mathrm{C}$, agitation of $150 \mathrm{rpm}$ with $2 \%$ inoculum $\left(10^{6}\right.$ spores $\left.\mathrm{mL}^{-1}\right)$. Biomass production was recorded continuously for six days and the protein content was also determined every day. From the observed results, Mucor hiemalis was found to be the most potential strain with biomass of about $11.48 \mathrm{~g} \mathrm{~L}^{-1}$ on the fourth day of treatment. With this promising result, the amount of bioprotein was further increased to $21.89 \mathrm{~g} \mathrm{~L}^{-1}$ by optimizing few process factors. Further optimization developments are in progress. This study may provide a better alternative in agricultural products by converting cheaper carbon source to valuable and quality product bioprotein, which can be used as supplement and additive in the animal feed and food as well as in chemical and pharmaceutical industries.
\end{abstract}

Key words: Mucor hiemalis, screening, biomass, liquid state bioconversion, optimization

\section{INTRODUCTION}

The significant increase in demand for livestock products in recent years in developing countries has required an increase in animal and human food supply. The importance of protein as food nutrient cannot be ignored because its deficiency can cause various malnutrition problems. This demands a search for new protein sources, with high nutritional value, economically feasible and locally available. Use of microbes as a food source is one of the biotechnological innovations that will certainly increase the availability of affordable protein in the world to solve the global food and feed problems. The production of bioprotein (protein derived from micro-organisms) by fermentation of wheat flour-a cheaper carbon source, is one of the most promising breakthrough of biotechnological innovations. This will certainly increase the availability of affordable good quality protein in the world. In addition to high quality, quantity will also be plentiful. It will reduce dependence on animal protein. This could be possible due to rapid growth rate of microorganisms and high production of bioproteins. Use of microbes as a food source may appear to be unacceptable for some people, but the idea of consumption of microbes as food for man is certainly innovative to successfully solve the global food problem ${ }^{[1]}$. Algae, fungi and bacteria are generally used as producers of bioproteins and can be utilized as a protein supplement because they are rich in protein, carbohydrates, fatty acids, vitamins and minerals. The protein extracted from cultivated microbial biomass, can be used for protein supplementation of a staple diet by replacing costly conventional sources like soymeal and fishmeal to alleviate the problem of protein scarcity ${ }^{[2]}$. The importance of protein in food nutrient cannot be neglected. Various malnutrition problems may occur due to protein shortage. This situation has created a demand for the formulation of innovative and alternative protein-rich food sources $^{[2]}$. In addition to this, the food route represents highest immediate cash return because demand for food is huge and will remain stable and the technologies involved are too cost effective.

Corresponding Author: $\quad$ Parveen Jamal, Bioenvironmental Engineering Research Unit (BERU), Department of Biotechnology Engineering, Faculty of Engineering, International Islamic University Malaysia (IIUM), P.O.Box 10, 50728 Kuala Lumpur, Malaysia, Tel: +603-6196 4558, Fax: +603-6196 4442 
Due to the increasing demand for bioprotein, the efficient strains, substrate and method must be used for higher level products. Various cheap carbohydrate sources are capable of supplying adequate calories to livestock such as wheat flour and cassava flour ${ }^{[3,4]}$. Wheat flour had long been are recognized as substrate that is full with nutrients and carbohydrate. Flour primarily consists of five nutrients: fat, minerals, moisture, starches and protein. Wheat flour could be a high quality substrate for bioprotein production due to its high carbohydrate (i.e. starch) value ${ }^{[5]}$. It is less expensive and easily available in Malaysia and other parts of the world. Therefore, in this research project, we introduced wheat flour as a cheaper carbon source for fermentation by a suitable microorganism to produce bioprotein. Selection of potential microorganism is necessary to produce maximum quantity bioprotein by liquid state bioconversion of substrate eg, wheat flour. Five different microorganisms-Aspergillus niger (A.niger), Phanerochaete chrysosporium (P.chrysosporium), Saccharomyces cerivisiea (S. cerivisiea), Mucor hiemalis(M.Hiemalis) and Thricoderma harzianum (T. harzianum) were selected from lab stock for screening. The experiment was conducted with fixed process conditions and the potential strain was selected on the basis of maximum biomass production and its protein content.

\section{MATERIALS AND METHODS}

Sample collection: Wheat flour, bought from the local market, is used as raw material in this study.

Microorganisms: Five different microorganismsAspergillus niger (A.niger), Phanerochaete chrysosporium (P.chrysosporium), Saccharomyces cerivisiea (S. cerivisiea), Mucor hiemalis(M.Hiemalis) and Thricoderma harzianum (T. harzianum) were collected from lab stock at International Islamic University Malaysia, University Putra Malaysia and some other places. All strains were cultured, maintained on (PDA) slants and stored at $4^{\circ} \mathrm{C}$. Subculture was done once a month.

Inoculum preparation: Inoculum preparation (spore suspension) was done according to the popular and amicable method suggested ${ }^{[6]}$. Cultures grown on PDA medium in petri dishes at $32^{\circ} \mathrm{C}$ for 7 days were transferred into Erlenmeyer flask $(250 \mathrm{~mL})$ containing $100 \mathrm{~mL}$ of sterile distilled water. It was then shaken in a rotary shaker at $150 \mathrm{rpm}$ for 24 hours. The suspended fungal cultures were filtered by Whatman \#1 filter paper and the filtrate was used as inoculum after measuring its concentration (spores $\mathrm{mL}^{-1}$ ) by Haemocytometer. Sterilization was done prior to addition of inoculum.

Screening: Screening was done in order to determine the potential strain for the maximum production of bioprotein. All selected strains were screened under controlled process conditions in $500 \mathrm{~mL}$ of Erlenmeyer flask having $2 \%(\mathrm{w} / \mathrm{v})$ of wheat flour. All experiments were conducted in a rotary shaker for six days by incubating at a temperature of $30^{\circ} \mathrm{C}$, agitation of 150 rpm with $2 \%$ inoculum $\left(10^{6}\right.$ spores $\left.\mathrm{mL}^{-1}\right)$. Biomass was recorded (three replicates) on 2 nd, $4^{\text {th }}$ and $6^{\text {th }}$ days.

Total protein determination: Protein determination was done according to Lowry et al. (1951) method

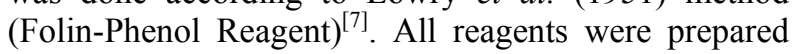
according to the suggested concentration and added to the sample solution as instructed in the method. Spectrophotometer reading was recorded at $660 \mathrm{~nm}$ after 20 minutes.

Biomass analysis: The biomass was filtered by vacuum filtration and washed three times with $20 \mathrm{~mL}$ of distilled water. Before taking the weight of the biomass, it was transferred into an aluminum disk and dried in an oven at $103^{\circ} \mathrm{C}-105^{\circ} \mathrm{C}$ for one hour followed by cooling in desicator to balance the temperature and weight ${ }^{[8]}$.

\section{RESULTS AND DISCUSSION}

Evaluation of potential microorganism: The images of each strain (A. niger, M. hiemalis, P. chrysosporium, $S$. cerivisiea and T. harzianum) cultured on PDA plate are shown in Fig. 1. Screening was done to determine the best microorganism that can produce highest protein and maximum amount of biomass by utilizing wheat flour.

Biomass production: Biomass concentration was one of the parameters used to evaluate the potentiality of microorganisms. The fermentation was conducted continuously for six days and each experiment was replicated three times. Biomass was determined on second, fourth and sixth days of the fermentation process. The concentration of biomass on different days of treatment period is shown in Fig. 2. All strains did not give similar trend for dried biomass concentration. T. harzianum and M. hiemalis obtained the optimum biomass of $10.7 \mathrm{~g} \mathrm{~L}^{-1}$ and11.4 $\mathrm{g} \mathrm{L}^{-1}$ respectively on $4^{\text {th }}$ 


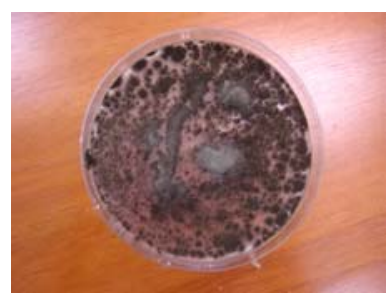

(a) A. niger

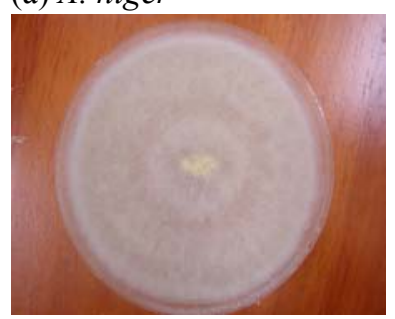

(c) M. hiemalis

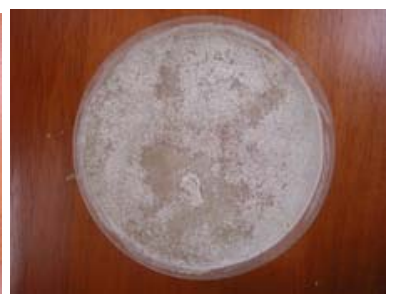

(b) P. chrysosporium

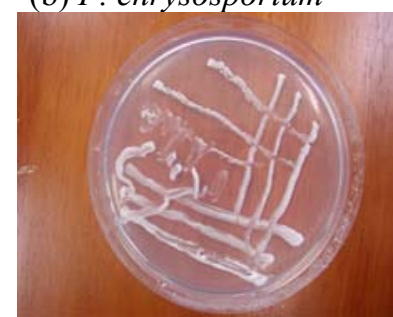

(d) S. cerevisiea

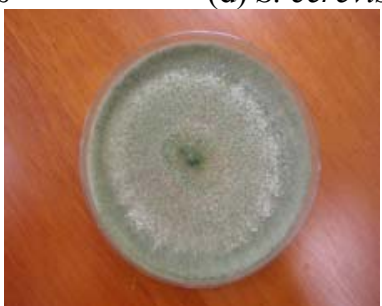

(e) T. harzianum

Fig. 1: Culture of microorganisms on PDA plate

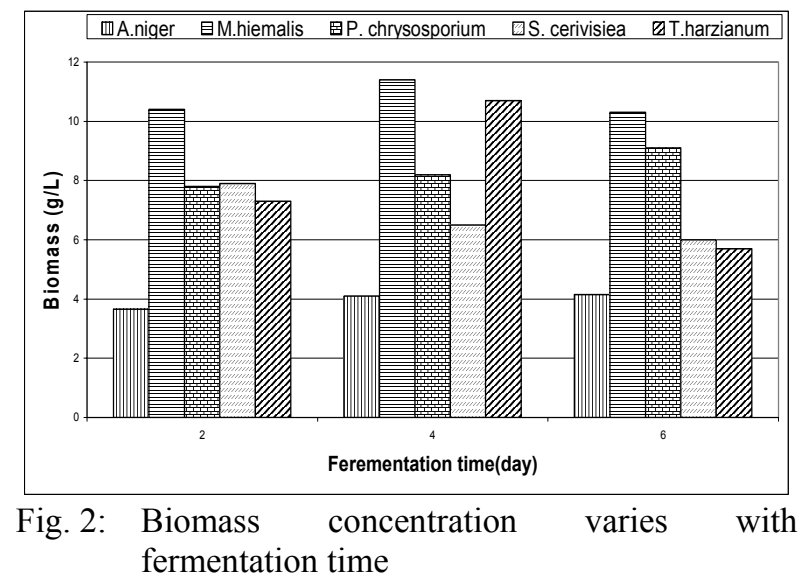

day with an increase from day 2 to day 4 and then decreased on 6th day. This result indicated that these strains were already in exponential phase on day 4 . After that they entered the death phase. A. niger showed a continuous growth until the last day of fermentation but the amount of biomass was lowest as compared to others. On the other hand, dried biomass of $S$. cerevisiea decreased gradually along the screening period from 7.9 to $6.5 \mathrm{~g} \mathrm{~L}^{-1}$ and $6.0 \mathrm{~g} \mathrm{~L}^{-1}$ on day 2,4 and 6 respectively.

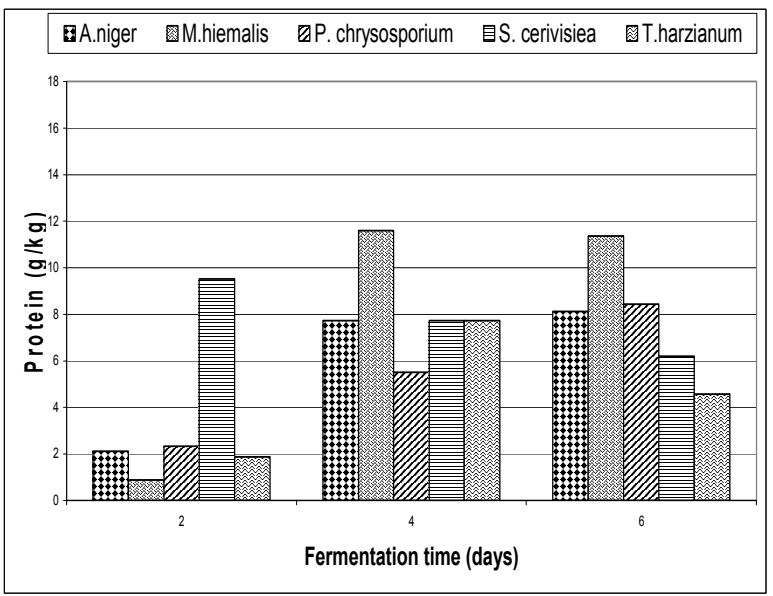

Fig. 3: Protein concentration varies with fermentation time

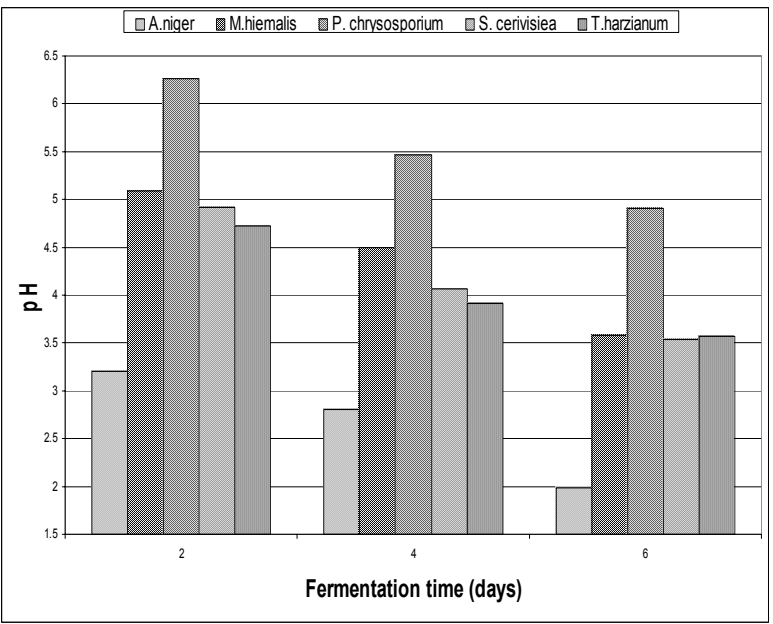

Fig. 4: $\mathrm{pH}$ varies with fermentation time

P. chrysosporium showed good growth of $9.1 \mathrm{~g} \mathrm{~L}^{-1}$ on the sixth day of fermentation. This biomass concentration could not be considered as highest biomass concentration because this strain did not reach maximum growth yet and were still in growth phase. Considering the growth curve in batch fermentation, generally, the biomass should increase exponentially as the cell is growing and when the cells enter the decline phase or death phase, biomass will decrease ${ }^{[9]}$.

Protein concentration: The concentration of protein in biomass during sixth days olong fermentation period is shown in Fig. 3. The protein productions by each strain slightly differ from each other. The fermentation time for maximum production of bioprotein was different for every microorganism. $A$.niger and $P$. chrysosporium showed highest concentration on sixth day, $M$. hiemalis 
Am. J. Biochem. \& Biotech., 3 (2): 42-46, 2007

\begin{tabular}{llccc} 
Table 1: & \multicolumn{4}{l}{ Values of bioprotein with change in media composition } \\
\hline Run & $\begin{array}{l}\text { Wheat } \\
\text { Flour } \\
\left(\mathrm{g} \mathrm{L}^{-1}\right) \mathrm{X}_{1}\end{array}$ & $\begin{array}{l}\mathrm{NH}_{4} \mathrm{NO}_{3} \\
\left(\mathrm{~g} \mathrm{~L}^{-1}\right) \mathrm{X}_{2}\end{array}$ & $\begin{array}{l}\mathrm{KH}_{2} \mathrm{PO}_{4} \\
\left(\mathrm{~g} \mathrm{~L}^{-1}\right) \mathrm{X}_{3}\end{array}$ & $\begin{array}{l}\text { Bioprotein } \\
\text { concentration } \\
\left(\mathrm{g} \mathrm{L}^{-1}\right)\end{array}$ \\
\hline 1 & 1.5 & 0.2 & 0.05 & 7.308 \\
2 & 1.5 & 0.2 & 0.15 & 9.026 \\
3 & 1.5 & 0.4 & 0.05 & 8.99 \\
4 & 1.5 & 0.4 & 0.15 & 10.146 \\
5 & 3.5 & 0.2 & 0.05 & 19.18 \\
6 & 3.5 & 0.2 & 0.15 & 20.29 \\
7 & 3.5 & 0.4 & 0.05 & 21.7 \\
8 & 3.5 & 0.4 & 0.15 & 21.13 \\
9 & 0.5 & 0.3 & 0.1 & 3.249 \\
10 & 4 & 0.5 & 0.1 & 21.89 \\
11 & 2.5 & 0.1 & 0.1 & 14.69 \\
12 & 2.5 & 0.5 & 0.1 & 20.53 \\
13 & 2.5 & 0.3 & 0 & 10.35 \\
14 & 2.5 & 0.3 & 0.2 & 16.322 \\
15 & 2.5 & 0.3 & 0.1 & 18.44 \\
16 & 2.5 & 0.3 & 0.1 & 18.368 \\
\hline
\end{tabular}

and $T$. harzianum on fourth day while $S$. cerevisiea on second day of fermentation. The strain M. hiemalis showed the highest protein concentration of $11.6 \mathrm{~g} \mathrm{~kg}^{-1}$ and $11.4 \mathrm{~g} \mathrm{~kg}^{-1}$ on second and fourth day of fermentation respectively as compared to other strains. Although two strains, $A$.niger and $P$. chrysosporium had an increasing trend until the last day (sixth day), but the protein concentration was not as high as $M$. hiemalis on fourth day. Even though $S$. cerevisiae had highest biomass concentration of $9.5 \mathrm{~g} \mathrm{Kg}^{-1}$ on the second day itself as compared to other strains, we could not select it as a potential strain due to a decrease in concentration after that. One of the objectives of this project is to obtain maximum concentration of bioprotein. Therefore, M. hiemalis was more preferable in this case because this strain produced highest biomass as well as high concentration of protein.

pH variation: The values of $\mathrm{pH}$ for all the samples with different microorganisms can be seen in Fig. 4. All five microorganisms showed a decreasing trend in the $\mathrm{pH}$ values. The variation in $\mathrm{pH}$ is different for every strain. The lowest $\mathrm{pH}$ was observed for Aspergillus niger. On the day 6 , the measured $\mathrm{pH}$ of $A$. niger was 1.98. It was expected so because $A$. niger had been widely used in citric acid production ${ }^{[10]}$. This $\mathrm{pH}$ is strongly acidic and not suitable for bioprotein or food production. For $P$. chrysosporium, it was less acidic on the last day as compared to other microorganisms. $T$. harzianum, $M$. hiemalis and $S$. cerevisiea, the value of $\mathrm{pH}$ was almost same on the day 6 . On the fourth day, the $\mathrm{pH}$ of $M$. hiemalis was 4.5 and it seems to be suitable for maximum biomass production and protein concentration.
Media optimization for bioprotein production: After selecting $M$. hiemalis as the potential strain for the bioprotein production using wheat flour as a substrate, we evaluated its performance by improving media compositions. Three factors were selected for optimization of media; wheat flour concentration $\left(\mathrm{X}_{1}\right)$, nitrogen concentration $\left(\mathrm{X}_{2}\right)$ and nutrient supplement concentration $\left(\mathrm{X}_{3}\right)$. Bioprotein concentration was recorded on the 4th day of fermentation. The experimental results showed an increase in the bioprotein concentration up to $21.89 \mathrm{~g} \mathrm{~L}^{-1}$ (Table 1).

\section{CONCLUSION}

Screening was done to select the best strains for bioprotein production by evaluating the strains in terms of total concentration of biomass and bioprotein produced. From the observed results, Mucor hiemalis was identified as the most potential strain for the maximum bioprotein production having a concentration of about $11.598 \mathrm{~g} \mathrm{Kg}^{-1}$ on the fourth day of treatment. The maximum biomass of $11.4 \mathrm{~g} \mathrm{~L}^{-1}$ was also obtained on fourth day of fermentation of wheat flour. The performance of the potential strain was satisfactory during media optimization. The study for the optimization of the process conditions is under progress and hopefully the amount of bioproteins can be further increased. This study may provide a better alternative by converting cheaper carbon source into useful and valuable bioprotein, which can largely be used as supplement and stabilizer in food and feed as well as an additive in the chemical and pharmaceutical industries.

\section{REFERENCES}

1. Uysal, H., M.N. Aydogan and O.F. Algur. 2002. Effect of single cell protein as protein source in Drosophilla culture. Braz. J. Microbiol., 33: 314317.

2. Anupama, P.R., 2000. Value-added food: Single cell protein. Biotechnol. Adv., 18: 459-479.

3. Balagopalan, C. and G. Padmaja, 1988. Protein enrichment of cassava flour by solid state fermentation with Thricoderma pseodokonigii Rifai for cattle feed. Proc. 8th Symp. International Society for Tropical Root Crops. Bangkok, Oct. 30-Nov.5, pp: 426-432.

4. Montesinos, T. and J.M. Navarro, 2000. Production of alcohol from raw wheat flour by Amyloglucosidase and Saccharomyces cerevisae. Enzyme and Microbial Technol., 27: 362-370. 
5. Dickerson, P. and P. Johnson, 2004. World population information. http://www. census. gov/ipc /www/ world. html.

6. Alam, M.Z., A.F. Razi and A.H. Molla, 2004. Evaluation of fungal potentiality for bioconversion of domestic wastewater sludge. J. Environ. Sci., 16: 132-137.

7. Lowry, O.H., N.J. Rosebrough, A.L. Farr and R.J. Randall, 1951. Protein measurement with the Folin phenol reagent. Biol. Chem., 193: 265-275.
8. APHA, 1989. Standard Methods for the Examination of Water and Wastewater. 17th Edn., American Public Health Association, Washington, DC.

9. Doran, P.M., 1995. Bioprocess Engineering Principle. Academic Press, London, pp: 277.

10. Jamal, P., M.Z. Alam, M.R.M. Salleh and M.M. Nadzir, 2005. Screening of microorganisms for citric acid production from palm oil mill effluent. Biotechnology, 4: 275-278. 